\title{
THE ENGLISH LANGUAGE PROFICIENCY AS A GLOBAL EMPLOYMENT SKILL: THE VIEWPOINT OF PAKISTANI ACADEMIA Furrakh Abbas $^{1 *}$, Abdul Majid Khan Rana ${ }^{2}$, Irfan Bashir ${ }^{3}$, Azhar Munir Bhatti ${ }^{4}$ \\ ${ }^{1 *}$ School of Languages, Civilization and Philosophy, University Utara Malaysia, Malaysia; ${ }^{2}$ Institute of Education and Research, The University of Punjab, Lahore, Pakistan; ${ }^{3}$ Department of Education, University of Management and \\ Technology, Lahore, Pakistan; ${ }^{4}$ Lecturer in English, Higher Education Department, Punjab, Pakistan. \\ Email: ${ }^{1 *}$ Furrakh.abbas@gmail.com, ${ }^{2}$ majid.ier@pu.edu.pk, ${ }^{3}$ irfanbashir@umt.edu.pk, ${ }^{4}$ azharmunir18@gmail.com
}

\section{Article History: Received on $6^{\text {th }}$ April 2021, Revised on $25^{\text {th }}$ May 2021, Published on $21^{\text {st }}$ June 2021}

\begin{abstract}
Purpose of the Study: The current research aims at exploring the need of effective English skill as a global employment skill and its various reasons, as there are various Pakistani institutes which are dedicated to The English language teaching and reinforce its relationship with employability. The importance of the study being conducted in Pakistan becomes more evident as English enjoys the status of the second language in the country.
\end{abstract}

Methodology: Current study uses a mixed-method research design and employs both questionnaires and interviews as research instruments. The questionnaire was administrated on a sample of 392 university students while a sample of 13 informants from university faculty participated in an interview for data collection.

Main Findings: The study concludes that the importance of English was associated with increased connectivity due to globalization. The study also concludes that the importance of English for finding jobs and making a career was wellestablished. To conclude, it can be said that English language proficiency is amongst the top global employment skills in the viewpoint of Pakistani academia.

Application of this Study: The study implicates that the importance of English for employment across the globe and a successful career will further lead to the formulation of English Specific courses for different professional and occupational groups in Pakistan.

The originality of the Study: There is a scarcity of empirical evidence in terms of the importance of English as an employment skill though English is considered very important as an elite language and a status symbol. The study proposes to fill in the gap by providing empirical evidence, therefore, the research is being conducted to assess the status of English and its importance for global employment skills.

Keywords: English, Globalization, Employment Skills, Academia, Pakistan.

\section{INTRODUCTION}

Pakistan is a developing country that remained a colony of British colonizers as part of India before 1947. Consequently, English became institutionalized as the language of the elite during that period and has occupied the same status (Abbas, Jalil, Zaki \& Irfan, 2020) despite the decolonization and liberation of India in two parts; India and Pakistan. Even after seven decades of freedom from British rule, the English language enjoys elite status. The influence of the English language in Pakistan is reflected in its use in all spheres of power such as bureaucracy, judiciary, and legislation (Abbas et al., 2019). It is considered a status symbol, a ladder to ascend socially, and a passport to success in life (Durga, 2018; Gazzola \& Mazzacani, 2019).

Illustrating the importance of communication in English, Pandey and Pandey (2014) concluded that it is very important because of its global impact. Durga (2018) furthered this argument and considered the English language as a tool in the workplace that could assure success to promotion in any working environment. The Pakistani public has also given importance to this language, as the education system - the most important department of life - has been influenced by the use of language which often creates a stratified society based on knowing and not knowing the English language (Parveen \& Mehmood, 2013; Abbasi, 2014). Jang et al., (2015) enumerated attitude, self-concept, value, interest, selfefficacy, and goal as the most important factors for motivation towards English language learning. The teachers need to work on these factors to boost the motivation of the students to work hard. So that, they could be prepared for the future job market by being better competitors.

There is a large number of English medium schools operative in the country which indicates the importance of the English language (Abbas \& Iqbal, 2018). The educational system of Pakistan has played an important role in asserting the significance of this language by teaching it as a subject as well as using it as the medium of instruction at a higher studies level as well (Abbas et al., 2018). Hussain (2018) emphasized that teachers should work on bridging the gap between the teaching process and the assessment techniques. As the techniques and process should be aligned with the job market; for which, professional trainers can work. The present study aims at investigating the perceptions of the Pakistani academia regarding the need for English language skills for future employment and its various reasons.

The job market in Pakistan and elsewhere abroad requires expertise in the English language (Al-Issa, 2014). There are studies on the relationship between English language proficiency and the job market and each study emphasizes the 
importance of English language proficiency (Xiong \& Yuan, 2018; Doan \& Hamid, 2019). The Pakistani market is no exception, which provides impetus to initiate the current research to explore the English language as a key factor to finding employment in the near and far future in the global world.

The present study aims at investigating English language proficiency as a global employment skill in the viewpoint of Pakistani academia.

\section{LITERATURE REVIEW}

Globalization which has created an impact on all walks of life has also helped the spread of English (Appadurai, 2001). Globalization has transformed English into the predominant language of the world (Rahman, 2020) and it is the prominently used language in almost every walk of life. It is used as an international language and remains the official language of many countries besides its role as the language of instruction, particularly of advanced education (Kamran \& Mansoor, 2017).

Scholars and researchers have attempted to label this strong connection between the English language and globalization under various terms: English as Lingua Franca (Jenkins, 2007), English as International Language (Sharifian, 2009), or World Englishes (Crystal, 2003). So, research on the role of English in Pakistani culture and other creating nations unfolds that this language is utilized as a gateway to enter into prestigious social positions (Coleman, 2010; Haidar and Fang, 2019). Thus, English plays a pivotal role in assessing the suitability of graduates for gaining employment. The importance of English in international student mobility has also been well recognized for many years, as manifested in the international English language competency tests.

It is a question of whether the next generation is prepared for the upcoming job market which requires proficiency in the English language, and this is the question in front of the academicians; for which, they are working hard to design different courses, creating syllabuses, writing books (Adebola, 2019). This has become a great motivation for science and arts faculties as they are working in the same domain which is other than their main fields (Hussain, 2018; Boothby \& Milojević, 2021). Hussain (2018) particularly is working on the academic motivation of the students regarding the English language proficiency for the job market. His study resulted that it is a challenge to motivate adult learners to drive their desires for learning English, but the only way is to attach the English language for the job scenario. He concluded that in this way, English language learning motivates them to work hard to achieve the required proficiency to have their job share in the market.

English has been perceived as the most widely used language in the present globalized world with its free-market economies. Good English is considered an integral factor in expanding employment opportunities (Sultana, 2016), enabling the masses to use and communicate via the internet, communicate with foreigners, increase their knowledge, and travel to other countries. Therefore, it is the source of widening their horizons in future lives and bringing empowerment to their lives. Capability and proficiency in English will undoubtedly increase employability by boosting basic skills to get, keep and do well in a job. For that purpose, English used at the workplace is required that is different from the language used for general communication (Durga, 2018). As there is specific terminology, and lexemes are required to be used at the workplace, which is normally not used in general communication, so to learn those terms, are necessary for communicating at the workplace (Rao, 2016).

The importance of English has been studied from the perspective of tourism and hospitality purpose and it found very positive results (Zahedpisheh et al., 2016). They work on the validity of English courses for the benefit of ETP (English for tourism purpose) because the industry of tourism and hospitality is international. The employees relating to this industry need proficiency in the English language so that they could meet their professional requirements and they would also be able to serve the people with quality. The study resulted that specific teaching material is required to teach students so that they could be prepared for employment in their favorite industry. Youngblood et al., (2020) also conducted a study to compare English language learning with the needs of the job market, again the focus was on the hotel industry and human resource management. He also recommended that English is very much necessary for the students so that they could easily adopt to the job and place themselves in the concerned market. The study on the importance of English for the hotel industry in Pakistan is also conducted by (Yasmin et al., (2016), and researchers also recommended that English is more than necessary for the students to be adopted in the industry of hotel management.

On the other hand, the deficiency in the English language communication skills among present-day undergraduates and graduates is identified as a factor influencing their prospects of securing employment, especially in the private sector (Sultana, 2016). The English language is used to project a positive image, acquire native characteristics, marginalize others, obtain communicative competence, adopt the western way of life and integrate with the global community. Thus, these desires can keep learners motivated both intrinsically and extrinsically (Ryan \& Deci, 2000 Vansteenkiste et al., 2018) as some desires are related to learners' imagined identities (Early \& Norton, 2012), while others are about the practical utility of the English language. The researchers, Motha and Lin (2014) suggested that the students' desire compels them to make tremendous, sometimes unfathomable sacrifices to gain access to the English language. The current research aims at exploring the perceptions of Pakistani academic concerning the importance of English for future employment. 


\section{RESEARCH METHODOLOGY}

The current research uses a mixed-method research design and employs both questionnaires and interviews as the research instruments. The reason for using a mixed-method study is to validate the results of both qualitative methods of data collection and to produce a composite illustration regarding the viewpoints of academia regarding English language proficiency as a top global employment skill.

The quantitative part of the research was conducted by using a questionnaire, administered to a sample of 392 university students. The sample was selected from universities as the current research aimed at exploring the perceptions of the Pakistani academia including both students and teachers. The sample for the questionnaire was selected from amongst the students while the sample for the qualitative section comprised of the university teachers. The sample for the questionnaire was selected randomly from the universities with the inclusion criteria as enrolment in any of the chosen universities and besides that, it was ensured that they must have spent at least 2 years in the university so that they could comment upon the survey knowing university education. The questionnaire was developed on the Likert scale and comprised of 12 statements.

The interview was conducted from a sample of 13 university faculty members. The interview questions were related to the need for English and the various reasons for which it was considered as a top global employment skill. The faculty members were selected based on their experience of more than 5 years as inclusion criteria. This inclusion criterion was based on permanent employment to gain better insight into the viewpoint of the faculty members.

The quantitative data were analyzed by using descriptive statistics in form of the mean score and standard deviation while the qualitative data was analyzed manually by identifying important themes and conducting an analysis based on these themes. The themes were not pre-decided but rather emergent as the interview was semi-structured and answerrelated probes were used to gain depth of opinion from the informants of the study.

\section{RESULTS AND DISCUSSION}

This section of the paper comprises two sections; the first section would discuss the findings from the quantitative data collected through a questionnaire, while the second section would provide insights through the analysis of qualitative data collected through interviews. The questionnaire used for the current research was developed on the Likert scale, and there were 12 statements related to the construct in the questionnaire. The statement wise mean score and standard deviation on different statements in the questionnaire are given in table 1 below:

Table 1: Statement wise mean score and standard deviation on the questionnaire

\begin{tabular}{llll}
\hline S \# & Statement & MS & SD \\
\hline 1 & The English language helps me connect with the whole world. & 4.23 & 0.94 \\
\hline 2 & The English language is a source of broadening my cultural horizons. & 4.61 & 0.70 \\
\hline 3 & The English language has become very important in the age of globalization. & 4.53 & 0.84 \\
\hline 4 & The English language helps me present my ideas elaborately. & 3.83 & 0.98 \\
\hline 5 & The English language is a matter of social prestige. & 4.58 & 0.82 \\
\hline 6 & The English language shows me as a modern man. & 4.56 & 0.70 \\
\hline 7 & Speaking The English language earns me respect from other people. & 4.24 & 0.99 \\
\hline 8 & The English language skills are integral for better jobs. & 4.10 & 0.97 \\
\hline 9 & The English language is required for making a presentation to share my work progress. & 3.62 & 1.15 \\
\hline 10 & The English language is a source of economic advantage in my society. & 4.05 & 0.85 \\
\hline 11 & English language skills are essential for my future career. & 4.38 & 0.98 \\
\hline 12 & The English language presents my personality in terms of my literacy. & 4.41 & 0.81 \\
\hline
\end{tabular}

$\mathrm{MS}=$ Mean score, $\mathrm{SD}=$ Standard Deviation

There were twelve statements on the questionnaire developed on a 5-point Likert scale. Table 1 shows the mean score and standard deviation on the different statements included in the questionnaire. The table shows 4 statements in the instrument for which the mean score was recorded to be 4.5 or above. These were; *) The English language is a source of broadening my cultural horizons [Mean score $=4.61$ ], $*$ ) The English language is a matter of social prestige [Mean score $=4.58], *)$ The English language shows me as a modern man [Mean score $=4.56$ ] and $*$ ) The English language has become very important in the age of globalization [Mean score $=4.53$ ]. The highest mean score was recorded for the statement related to broadening the cultural horizons while the score on the other statement was also above 4.5; there was a closeness in the responses as shown in the mean score on all four statements mentioned here.

There were six statements on which the mean score of the respondents ranged between 4 and 4.49 . The statements and the mean score in descending order as given in the table were; *) The English language presents my personality in terms of my literacy [Mean score $=4.41$ ], *) The English language skills are essential for my future career [Mean score $=$ 4.38]*) Speaking the English language earns me respect from other people [Mean score $=4.24],^{*}$ ) The English language helps me connect with the whole world [Mean score $=4.23$ ], *) The English language skills are integral for better jobs 
[Mean score $=4.10$ ], and $*$ ) The English language is a source of economic advantage in my society [Mean score $=4.05$ ]. There were two statements of the questionnaire for which the mean score was found to be lesser than four, and these statements and the mean score on these statements was; *) The English language helps me present my ideas elaborately [Mean score $=3.83$ ], and The English language is required for making a presentation to share my work progress [Mean score $=3.62]$. The results show that on most of these statements, the mean score was above 4 which means that the respondents considered the English language skills integral to future employment.

The second research instrument used for the current study was the interview, and 13 university faculty members participated in data collection through the interview process. The data was transcribed for the themes to emerge lucidly and adequately. The purpose of the interview was to gain insight into various reasons for which English has been integral to future employment. The informants who participated in interviews were experienced academicians with more than five years of university-level teaching experience. The data of the interview showed that the most important reason was the internationalization of the English language. The informants cited;

English is truly an international language as you can interact with the whole world using the English language (Informant \# 5)

With good the English language, you can find jobs in your profession in all countries (Informant \# 12).

The informants expressed their opinion that English is an important skill to excel in the future. They argued that among the top sought skills for future employment, English is amongst the top skills. Besides the knowledge of your profession and ethics, language skills in English are crucial to success at the job. Not only this provides you with an edge over others, but it is also the ladder of your professional success. Some informants discussed that the job interviews are conducted in English, so its importance in finding a job is also very significant. The informants quoted;

Job interviews are mostly conducted in the English language, so it is definitely important (Informant \# 2).

The English language skill is like a pre-requisite to professional success (Informant \# 6).

English is amongst the top future skills (Informant \# 11).

Enlisting the reasons for the importance of English in future employment, the informants cited that the world has become a global village. It is easy to interact with people from across different countries, and this happens through the English language as they do not understand the language of one another. There are so many multinational companies that have employees from many countries, so it serves a crucial role for them in these companies. There is increased interconnectivity among the people from a different region, and the credit for this goes to English as well. The informants expressed their opinion saying;

The role of English for future is also because of its status as global lingua-franca (Informant \# 10).

Multinational companies use English to communicate with their employees from different nationalities and countries (Informants 12).

The informants believed that English enjoys a high academic value, so its importance in future employment is also higher. The data from the interviews implicated that there are so many international students registered in universities outside their home country, and English is their source of communication. The academic value of the English language is higher because most of the international conferences are held in the English language across the globe. The research published in the world also uses English as its primary language, and if there are any journals in other than the English language, they publish abstracts in English for the readers at least. The informants viewed the association of English with academics and future employment as;

English is the language of international conference and research (Informant \# 6)

International students use English to interact as it is the medium of communication in higher education in most of the universities that attract students internationally (Informant \# 11).

The data from the interviews show that the informants attached English with finding employment and excelling in their careers. The informants exhibited their opinion that the importance of English has been associated with increased connectivity due to globalization. The role of English as a global lingua-franca has resulted in its international acceptance for multinational companies. English is also the language of academics and research, so its future employment is bound to be higher.

\section{CONCLUSION}

The current study was conducted to investigate the perceptions of academia regarding the need for English language skills for future employment and its various reasons. The study concludes that English is amongst the top-sought skills for jobs in the future. Durga (2018) also proposes a similar argument that the English language is a tool in the workplace that could assure success to promotion in any working environment. Hence, it can be concluded that the job market in Pakistan and elsewhere abroad requires expertise in the English language (Al-Issa, 2014). The educational system of 
Pakistan has played an important role in asserting the significance of this language by teaching it as a subject as well as using it as the medium of instruction at a higher studies level as well (Abbas et al., 2018). There are many similar studies on the relationship between English language proficiency and the job market and each study emphasizes the importance of English language proficiency (Xiong \& Yuan, 2018; Doan \& Hamid, 2019). The importance of English was associated with increased connectivity due to globalization. The role of English as a global lingua-franca has resulted in its international acceptance for multinational companies. English is also the language of academics and research, so its future employment is bound to be higher. The study concludes that the importance of English for finding jobs and making a career was well-established. Hussain (2018) also describes in his study earlier that English language learning motivates people to work hard to achieve the required proficiency to have their job share in the market. Good English is considered an integral factor in expanding employment opportunities (Sultana, 2016). The findings of the present study are similar to Youngblood et al. (2020) who recommends that English is very much necessary for the students so that they could easily adapt to the job and place themselves in the concerned market. The study implicates that the future of English for employment will further lead to the formulation of English Specific courses for different professional and occupational groups in Pakistan.

\section{LIMITATIONS AND STUDY FORWARD}

The current study was limited in the sense that it assessed the importance of the English language for global employability in the perspectives of Pakistani academia. It can be expanded to include the perceptions of some specific industries in Pakistan because there is a lack of research studies regarding ESP courses and their relatedness to the job market. There is a dire need to conduct studies to validate different professional courses conducted by different institutions in Pakistan for preparing the students for some specific job markets.

\section{AUTHOR'S CONTRIBUTION}

Furrakh Abbas worked on developing the concept of the article, developing research instruments and writing introduction section as well as editing the whole document for grammatical accuracy and clarity.

Abdul Majid Khan Rana developed the literature review section and organized the references.

Irfan Bashir analyzed the data and wrote the interpretation of data.

Azhar Munir Bhatti developed discussion on the data analysis and linked it to the literature review section.

\section{REFERENCES}

1. Abbas, F, Anjum, K. \& Pasha, S. B. (2019) Speech act of apology by Pakistani English speakers through the theory of politeness. The Dialogue, 14 (2), 196-213.

2. Abbas, F., Jalil, M. K., Zaki, H. N. \& Irfan, F. (2020). Implicit measure of language attitude: study of Punjabi native speakers by using matched guise technique. International Journal of Innovation, Creativity and Change, 13 (1), 194-206.

3. Abbas, F. and Iqbal, Z. (2018). Language Attitude of the Pakistani Youth towards English, Urdu and Punjabi: A Comparative Study. Pakistan Journal of Distance and Online Learning, 4 (1), 199-214.

4. Abbas, F., Pervaiz, A. and Arshad, F. (2018). The competing status of Urdu and English after declaration of Urdu as official language in Pakistan. Journal of Research (Urdu), 34 (1), 142 - 158.

5. Abbasi, M. A. (2014). Towards the de-radicalization of Pakistani society: The need for a balanced and progressive education system. Dialogue, 9(3), 256-270.

6. Adebola, L. O. (2019). How Well Prepared Are Chilean Beginning English Teachers to Meet Job Demands in The English language Teaching Industry? Journal of Entrepreneurship Education, 22(6), 1-12.

7. Al-Issa, A. S. (2014). Researching the uses of the English language in the law job market in the sultanate of oman: implications for policy-practice improvement. Educational Research for Policy and Practice, 13(1), 2544. https://doi.org/10.1007/s10671-013-9146-4

8. Alrabai, F. (2014). Motivational practices in English as a foreign language classes in Saudi Arabia: Teachers beliefs and learners perceptions. Arab World English Journal, 5 (1), 224- 246.

9. Alston, A. J. et al. (2009). The Importance of Employability Skills as perceived by the employers of United States Land-grant College and University Graduates. Journal of Southern Agricultural Education Research, 59 (1), 56-69.

10. Appadurai, A. (1990). Disjuncture and Difference in the Global Cultural Economy. Theory, Culture and Society, 7(2-3), 295-310. https://doi.org/10.1177/026327690007002017

11. Appelbaum, S.H., Hebert, D. and Leroux, S. (1999). Empowerment: Power, Culture and leadership: A strategy or fad for the millennium? Journal of Workplace Learning: Employee Counselling Today, 11(7), 233-54. https://doi.org/10.1108/13665629910291929

12. Boothby, C., \& Milojević, S. (2021). An exploratory full-text analysis of Science Careers in a changing academic job market. Scientometrics, 126(5), 4055-4071. https://doi.org/10.1007/s11192-021-03905-2 
13. Boud, D. and Middleton, H. (2003). Learning from others at work: communities of practice and informal learning. Journal of Workplace Learning: Employee Counselling Today, 15(5), 194-202. https://doi.org/10.1108/13665620310483895

14. Bourdieu, P. (1991). Language and Symbolic Power. Cambridge: Polity Press and Harvard University Press.

15. Brew, A., \& Jewell, E. (2012). Enhancing quality learning through experiences of research based learning: Implications for academic development. International Journal for Academic Development, 17(1), 47-58. https://doi.org/10.1080/1360144X.2011.586461

16. Brown, B.S. and Emmett, D. (2001). Explaining variations in the level of academic dishonesty in studies of college students: some new evidence. College Student Journal, 35(4), 529-39.

17. Caruana, A., Ramaseshan, B. and Ewing, M.T. (2000). The effect of anomie on academic dishonesty among university students. The International Journal of Educational Management, 14(1), 23-29. https://doi.org/10.11 08/09513540010310378

18. Cheah, H.B. and Yu, T.F.L. (1996). Adaptive response: entrepreneurship and competitiveness in the economic development of Hong Kong. Journal of Enterprising Culture, 4(3), 241-66. https://doi.org/10.11 42/S0218495896000149

19. Chew, S.B., Lee, K.H. and Quek, A.H. (Eds) (1995). Education and Work: Aspirations of Malaysian Secondary School Students. University of Malaya Press, Kuala Lumpur.

20. Christine, Z.J. and James, C.A. (2008). Personality traits and academic attributes as determinants of academic dishonesty in accounting and non-accounting college majors. Proceedings of the 15th Annual Meeting of American Society of Business and Behavioral Sciences (ASBBS), Las Vegas, NV, USA, 15(1), 604-16.

21. Coleman, H. (2010). Teaching and Learning in Pakistan: The Role of Language in Education. Islamabad: British Council.

22. Crystal, D. (2003). English as a Global Language. Cambridge: Cambridge University Press. https://doi.org/10.1017/CBO9780511486999

23. Dest. (2002). Employability Skills for the Future. March ACT, DEST.

24. Doan, L. D., \& Hamid, M. O. (2019). Economics of English: Examining the demand for English proficiency in the Vietnamese job market. RELC Journal, 0033688219863166. https://doi.org/10.1177/0033688219863166

25. Durga, M. V. S. S. (2018). The Need of The English language Skills for Employment Opportunities. Journal for Research Scholars and Professionals of The English language Learning, 7(2), 1-5.

26. Early, M., \& Norton, B. (2012). Language Learner Stories and Imagined Identities. Narrative Inquiry, 22(1), 194-201. https://doi.org/10.1075/ni.22.1.15ear

27. Gazzola, M., \& Mazzacani, D. (2019). Foreign language skills and employment status of European natives: evidence from Germany, Italy and Spain. Empirica, 46(4), 713-740. https://doi.org/10.1007/s10663-019-094607

28. Haidar, S. (2017). Access to English in Pakistan: Inculcating prestige and leadership through instruction in elite schools. International Journal of Bilingual Education and Bilingualism, 1-16. https://doi.org/10.1080/ 13670050.2017 .1320352

29. Haidar, S. (2018). The Role of English in Developing Countries: English is a passport to privilege and needed for survival in Pakistan. English Today, 35(3), 42-48. https://doi.org/10.1017/S0266078418000469

30. Haidar, S., \& Fang, F. G. (2019). The English language in education and globalization: A comparative analysis of the role of English in Pakistan and China. Asia Pacific Journal of Education, 39(2), 165-176. https://doi.org/10.1080/02188791.2019.1569892

31. Hussain, M. S. (2018). Motivating English as a Foreign Language (EFL) Adult Learners: Challenges to Prepare Them for Future and Job Market. International Research Journal of Arts \& Humanities (IRJAH), 46(46).

32. Iqbal, M. \& Rafi, M. S. (2018). A Comparative Study of The English language Teaching Practices at the Access Program and Public Schools. Bulletin of Education and Research, 40(3), 231-249.

33. Irani, F. N. H. A., \& Noruzi, M. R. (2011). Globalization and challenges: What are the globalization's contemporary issues. International Journal of Humanities and Social Science (IJHSS), 1(6), 216-218.

34. Jang, B.G.; Conradi, K.; Mckenna, M.C., and Jones, J.S. (2015). Motivation: Approaching an elusive concept through the factors that shape it. Reading Teacher, 69(20), 239-247. https://doi.org/10.1002/trtr.1365

35. Jenkins, J. (2007). English as a Lingua Franca: Attitude and Identity. Oxford: Oxford University

36. Kamran, S., \& Mansoor, S. (2017). Globalization and Language Use on Social Media in Pakistan. European Journal of Language and Literature, 8(1), 79-84. https://doi.org/10.26417/ejls.v8i1.p79-84

37. McCabe, D.L. and Trevino, L.K. (1997). Individual and contextual influences on academic dishonesty: a multicampus investigation, Research in Higher Education, 38(3), 379-96.

38. Minister of Education (2000). Science and technology education: challenges in the new millennium, 10th Public Lecture, Confederation of Scientific and Technological Association, Malaysia (COSTAM), Selangor, July.

39. Motha, S., \& Lin, A. (2014). "Non-coercive rearrangements": Theorizing desire in TESOL. TESOL quarterly, 48(2), 331-359. https://doi.org/10.1002/tesq.126

40. Nazir, M. S. and Shakeel, M.A. (2018). Academic dishonesty and perceptions of Pakistani students. International Journal of Educational Management, 24(7), 655-668. https://doi.org/10.1108/09 $\underline{513541011080020}$ 
41. Norton, B. (2000). Identity and Language Learning: Gender, Ethnicity and Educational Change. Harlow, UK: Longman.

42. Pandey, M., \& Pandey, P. (2014). Better English for better employment opportunities. International journal of multidisciplinary approach and studies, 1(4), 93-100.

43. Parveen, S., \& Mehmood, A. (2013). A Study on Attitudes towards Varieties of Spoken English in Pakistani Context. Language in India, 13(3).

44. Quek, A.H. and Soon, T.K. (1999). Research and Development Priorities in the New Millennium: Human Resource Management and Business Preferences in Malaysia. Malaysia Science and Technology Congress, Abstracts, Ministry of Science, Technology and Environment, Malaysia, Kuala Lumpur, pp. A68.

45. Quek, Ai-Hwa. (2005). Learning for the Workplace: A Case Study in Graduate Employees' Generic Competencies. Journal of Workplace Learning, 17(4), 231-242. https://doi.org/10.1108/13665620510597185

46. Rao, C. (2016). A brief study of the English language proficiency: Employability. English for Specific Purposes World, 17(49).

47. Rahman, T. (2020). Pakistani English. In The Handbook of Asian Englishes, 279-296. https://doi.org/10.1002/ 9781118791882.ch11

48. Rassool, N. (2013). The Political Economy of The English language and Development: English vs. National and Local Languages in Developing Countries. In Erling, E. J. \& Seargeant, P. (Eds.), English and Development: Policy, Pedagogy, and Globalization, 45-67. Toronto: Multilingual Matters. https://doi.org/1 0.21832/9781847699473-006

49. Ryan, R. M., \& Deci, E. L. (2000). Intrinsic and extrinsic motivations: Classic definitions and new directions. Contemporary educational psychology, 25(1), 54-67. https://doi.org/10.1006/ceps.1999.1020

50. Shamim, F. (2011). English as the Language for Development in Pakistan: Issues, Challenges and Possible Solutions. In Coleman, H. (Eds.), Dreams and realities: Developing Countries and the The English language (pp. 291-309). London: British Council.

51. Sharifian, F. (2009). English as an International Language: Perspectives and Pedagogical Issues. Clevedon: Multilingual Matters. https://doi.org/10.21832/9781847691231

52. Sultana, N. (2016). English for employment: students' proficiency and current demand of English in the development sector of Bangladesh. (Unpublished doctoral dissertation). BRAC University Bangladesh.

53. Vansteenkiste, M., Aelterman, N., De Muynck, G. J., Haerens, L., Patall, E., \& Reeve, J. (2018). Fostering personal meaning and self-relevance: A self-determination theory perspective on internalization. The Journal of Experimental Education, 86(1), 30-49. https://doi.org/10.1080/00220973.2017.1381067

54. Wye, C.K. \& Liew, C. S. (2009). Perception Differential Between Employers and Undergraduates on the Importance of Employability Skills. International Education Studies, 2(1), 96-105. https://doi.org/10.55 39/ies.v2n1p95

55. Yasmin, M., Sarkar, M., \& Sohail, A. (2016). Exploring English language needs in the hotel industry in Pakistan: An evaluation of existing teaching material. Journal of Hospitality \& Tourism Education, 28(4), 202213. https://doi.org/10.1080/10963758.2016.1226846

56. Youngblood, A. M., Nutta, J. W., Dickson, D. R., \& Nutta, M. W. (2020). Learning English as a second language in the back-of-the-House: proficiency and employment from the perspective of hotel human resource directors. Journal of Human Resources in Hospitality \& Tourism, 1-24. https://doi.org/10.1080/15 332845.2020.1821426

57. Xiong, T., \& Yuan, Z. M. (2018). "It was because I could speak English that I got the job": Neoliberal discourse in a Chinese English textbook series. Journal of Language, Identity \& Education, 17(2), 103-117. https://doi.org/10.1080/15348458.2017.1407655

58. Zahedpisheh, N., Bakar, A., Zulqarnain, B., \& Saffari, N. (2017). English for Tourism and Hospitality Purposes (ETP). The English language Teaching, 10(9), 86-94. https://doi.org/10.5539/elt.v10n9p86 